\title{
RESEARCH ARTICLE \\ Women and Gender Relations during the Pandemic in Morocco
}

\author{
Moha Ennaji \\ International Institute for Languages and Cultures, University of Fès, Morocco.
}

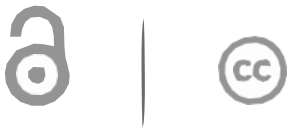

Open Access

Citation: Ennaji, M., Women and Gender Relations during the Pandemic in Morocco. Gender and Women's Studies. 2021; 4(1):3.

Received: September 14, 2020 Accepted: February 07, 2021 Published: February 14, 2021

Copyright: (C2021 Ennaji, M. This is an open access article distributed under the terms of the Creative Commons Attribution License, which permits unrestricted use, distribution, and reproduction in any medium, provided the original author and source are credited.

\section{Corresponding author:}

Moha Ennaji, International Institute for Languages and Cultures, University of Fès, Morocco. E-mail: mennaji2002@yahoo.fr

\begin{abstract}
Covid-19 has totally disrupted all activities and social affairs, including gender relations and men's and women's living conditions. This article focuses on the negative repercussions of the Covid-19 pandemic on women and gender roles in Morocco. It reveals that the pandemic has burdened women with more housework and duties at home, and that violence against them has risen, especially among working class women and housemaids who are particularly socio-economically vulnerable. Many of them have lost their income and feel isolated and lonely, with hardly any opportunity to recuperate their activity, to visit their relatives, or meet new people, and consequently no one to turn to for support. Domestic violence is the most common type of violence against women in Morocco during this pandemic. The fieldwork I conducted in Fès city and its region reveals that some women and girls are often beaten up by their husbands, fathers, or brothers and many cases of such incidents have reached courts and the media. However, these battered women rarely approach the police for assistance because they are often unaware of their legal rights, on the one hand, and because they believe that the police may be biased against them, on the other. Nevertheless, there is a silver lining in this crisis: in a few households, many men show willingness to help with the housework and to provide more care to their children's education and distance learning. The article ends with recommendations for reform of practices and laws with the purpose of eliminating violence against women in both the private and the public spaces, and proposes education, legislation, and law enforcement as valuable tools to combat such violence.
\end{abstract}

\section{Keywords}

Gender, women, men, pandemic, domestic violence, work, Morocco

\section{Introduction}

According to the World Health Organization (WHO), Africa could be the next epicenter after the United States if nothing is done to curb the pandemic. UN officials state that the Covid-19 pandemic will probably kill at least 300,000 people in Africa and drive nearly 130 million into poverty and famine. They have also underscored that the continent suffers from a dire shortage of hospital beds and ventilators to deal with this pandemic. ${ }^{i}$

In Morocco, the number of confirmed COVID-19 cases so far has been limited, despite the country's proximity to Europe. As of January 25, 2021 Morocco had a total of 466,626 cases and 8172 deaths, according to John Hopkins University Center.ii

As the Covid-19 pandemic has spread across North Africa since March 2020, the Moroccan government took severe measures to curb the progression of the disease, as we shall discuss shortly. These steps will have drastic effects on the economy, women, and gender relations.

The economy has suffered a huge setback as a result of the many restrictions on mobility, which negatively impacted the public and private sectors, especially tourism and other services. The health crisis has exposed the harsh reality of the average citizen, such as poor health care, inadequate policies and welfare, social and gender inequalities. 
Indeed, the Covid-19 pandemic has given the State free hand to manage the situation and impose the necessary restrictions. As a result, the State apparatus has been emboldened using different tools and measures to control the pandemic. In addition, it has quickly encouraged the production of facemasks, ventilators, hand-sanitizers and other medical supplies to help curb the disease.

However, the pandemic has flattened the economic growth by upsetting trade movements, plummeting tourism revenues, and causing higher public spending. These are substantial concerns for a country which, notwithstanding a few encouraging macroeconomic indicators, already suffers from structural economic problems, such as over-reliance on agriculture, tourism, and the remittances of Moroccan workers abroad. iii

The health and socio-economic crisis triggered by Covid-19 has hit everybody in Morocco, especially women and girls, which has exacerbated the already spreading feminization of poverty, domestic work and care load, and violence against women and girls. Underprivileged women cannot access health care, family planning, and education, particularly after over a million people have lost their jobs. Among the major areas of impact we can cite: i) greater care needs of the elderly, family members, and children due to home quarantines, school closures, and work from home, ii) augmented domestic violence; iii) disruption in reproductive health services and family planning; iv) dislocated education and nutrition systems due to reduced incomes of families. Lower attention for girls' education and inadequate nutrition will lead to reduced investments in these tiers. Additionally, lower incomes will increase child marriage when girls are seen as a problem (Ennaji, 2019); and v) loss of jobs and revenues. These factors have uncovered gender inequalities and have led to more feminization of poverty. This is further exacerbated by the fact that many men lost their jobs, which made them violent at home.

This study deals with the situation of women and gender relations during the Covid-19 crisis within a broader socio-political approach. It adopts the intersectionality theory, which underlines the interconnection of various kinds of oppression faced by women (Collins 2008; Crenshaw et al. 1996). This theory stresses the intertwined forms of oppression based on gender, race, class, politics, age, ethnicity, religion, citizenship, or appearance. These regular types of oppression may overlap in women's lives, leading to complex impacts.

This article is based on fieldwork I undertook between April and December 2020 in the region of Fès. It is also based on official documents and on previous research in the field by Moroccan and international scholars. The aim is to grasp their perceptions and opinions about the impact of Covid-19 crisis on gender relations and women, the obstacles they have encountered, and the progress made if any. Through participant observation, semi-structured interviews, and discourse analysis, this study focuses on the impact of the pandemic on women's lives, underscoring the main consequences on gender relations and on society as a whole. It discusses how the pandemic has disrupted and impacted the social fabric and gender roles over the past nine months in Morocco.

The main argument of this article is that the pandemic has brought about mostly negative change in gender relations and has worsened the socio-economic situation of women and men due to its devastating repercussions on the economy and on society. The article is divided into six sections. The first one is a review of the literature on the impact of the pandemic on women and gender relations. The second section introduces gender and women in the Moroccan context. The third outlines Morocco's economy and how the country has responded to Covid -19 . The fourth deals with the impact of the pandemic on women and gender relations. The fifth section discusses the data and the findings of the fieldwork. The sixth provides a number of recommendations to help overcome the difficulties and build a society of gender equity and justice.

Before presenting the context of gender relations and the status of women in Morocco, I will first briefly provide a review of the literature on gender relations during the pandemic.

\section{Review of the literature}

A few studies have discussed women and gender relations during the Covid-19 pandemic so far. A UN policy brief titled "The Impact of Covid-19 on women", published on April 9th 2020, affirmed that the health crisis was amplifying the current socio-economic inequalities, exposing weaknesses of the health and education systems which were in turn swelling the effects of the disease. 
COVID-19 is not only a challenge for global health systems, but also a test of our human spirit. Recovery must lead to a more equal world that is more resilient to future crises. Fiscal stimulus packages and emergency measures to address public health gaps have been put in place in many countries to mitigate the impacts of COVID -19. It is crucial that all national responses place women and girls - their inclusion, representation, rights, social and economic outcomes, equality and protection - at their centre if they are to have the necessary impacts. This is not just about rectifying longstanding inequalities but also about building a more just and resilient world. It is in the interests of not only women and girls but also boys and men. Women will be the hardest hit by this pandemic but they will also be the backbone of recovery in communities. Every policy response that recognizes this will be the more impactful for it.

According to UNESCO, globally lockdowns and school closures have kept about 90 percent of all students out of school. More than 1.5 billion children were out of school last May, ${ }^{\text {iv }}$ among them more than 800 million girls. Most of these girls live in poor and developing countries where joining school is already a struggle. Indeed, girls as a vulnerable group, have been severely impacted by the pandemic, hindering their education, and slowing down progress made toward gender equality. In their article, Mullet and Nathan (2020) warn that school closures during the pandemic may further widen existing gender gaps in education and reduce girls' empowerment, stifling any headway already made, chiefly in developing countries. $^{v}$

Brechenmacher and Hubbard (2020) have outlined how the health crisis may exacerbate women's exclusion. They argue that the pandemic is shrinking women's economic independence and swelling their unpaid housework. Moreover, "many women have taken on additional caregiving tasks, primarily due to disruptions in schooling and childcare." This new situation is aggravating current gender inequities which usually preclude women from participating in political life. The Covid-19 pandemic has also pushed women's rights to the side as secondary.

Sharafeldine (2020) underlines how the pandemic has "brought to the fore: domestic violence, women's labor participation, and unpaid domestic labor and care." She argues that crises such as Covid-19 intensify the negative impacts of the existing family laws in Muslimmajority countries which constitute hurdles to women's labor participation. Being aware that inequality in the family intersects with various other forms of inequalities, she calls for a reform of family laws in the Arab world arguing that "gender equality and justice are at the core of the Islamic message."

Covid-19 is increasing not only gender inequities, but also inequalities between different social groups of women. For example, middle-class or upper-class women are less likely to be negatively impacted or killed by the virus than poor women with no education, nor health care nor life insurance. As Moke Ryan, Executive Director of the WHO stated: "It's not just Covid -19 that is killing people, it's under-privilege, it's lack of access, it's years of living with health conditions that haven't been properly managed because of the color of your skin, or because of your ethnicity, or because of your social group."vi

Notwithstanding these difficult circumstances, the existing health crisis also presents prospects for improving women's lives and strengthening their political engagement. Firstly, women's rights researchers and activists state that they are observing the rise of "stronger feminist solidarity networks" (Brechenmacher \& Hubbard, 2020). From Poland to Argentina, women are more vocal than in the past, and feminists are finding wider audiences for women's issues and intake of the recent pandemic reactions. I am thinking of the recent women's protests against abortion restrictions in these two countries. In Morocco, women's rights activists have been able to connect with female and male politicians in order to share resources and calls for action.

In a UNDP human development paper, Rivera et al. (2020) stated that women have made significant progress in society at the economic and political levels; however, the pandemic "puts at risk the gains at the household level, hinders women participating in decision making and increases the risk of job losses."

In an article on Covid-19 in Tunisia, Amel Grami (2020) states that although there are female advisors to the prime minister for women's affairs and even specialized security institutions such as the community police for the protection of women against violence, the government "did not succeed in diminishing the impact of the culture of violence against 
women during the pandemic", and the State, as an authority and as a regulator of gender relations, did not succeed in changing this vision" because the patriarchal mind is still in control. Despite global activism to combat violence against women, the issue remains persistent in Morocco and worldwide, requiring further efforts, as we shall see shortly.

It is now evident that the pandemic has not only caused a global health disaster, but it has also produced a major global economic crisis. In this article, I present some preliminary findings about how this economic depression impacts gender relations and women and men, and the chief implications for gender equality. The literature on this topic has provided suggestions that the consequences of the pandemic on women and men are quite dissimilar from those of previous economic crises. In the 2008 recession, men's job damages were much bigger than women's job damages mainly because men usually worked in the industries that had relentlessly been impacted by "standard" contraction (such as manufacturing and construction), while women were working in social domains such as education and healthcare. Yet, the present pandemic has a major effect on social service professions with a high female employment rate, such as the tourism industry, cafés and restaurants (Alon et al. 2020; Puri, 2020).

A more significant grid for the distinct effects on women and men is that during the outbreak of the Covid-19 pandemic, Morocco along with other countries decided to close schools and daycare centers (Abouzzouhor, 2020). This greatly amplified the need for distance or home learning and childcare. Additionally, the childcare provided by grandparents has been discouraged since the start of the pandemic due to the odd mortality rate among the elderly, and due to preventive measures such as social distancing, the sharing of childcare with baby-sitters or others has been extremely restricted. Hence, many families have had to watch their own children. Given that traditionally and culturally women are the usual childcare givers, mothers are more likely to be overwhelmed than fathers. Widows, divorcees, and single mothers, who are often economically underprivileged, have suffered most. For these reasons, the pandemic has had a disproportionate negative impact on women. ${ }^{\text {vii }}$

A large body of literature documents that losses in profits from job losses during economic recessions are very important (Davis et al. 2011). Employees and workers who have lost their jobs are more probably going to remain unemployed longer after the end of the pandemic. The effects do not concern only those who lost their jobs, but also new university graduates who are looking for jobs for the first time. viii However, it is possible that this might provoke positive changes that could curb gender inequalities in the family and in the job market in the future. Today, the health crisis has exacerbated the gender inequality in the job market, which is linked to the unbalanced division of labor in the family. These factors are considered to be gender-based, i.e., determined by the social and cultural norms and practices that differ between genders.

Although women's participation in the workforce is better than three decades ago, it is still far from equal to that of men, as women continue to assume most of the household chores and childcare. Recent literature on women during the pandemic has documented that the gender wage gap is closely associated to the housework responsibilities and the birth of children (Alon et al. 2020; Brechenmacher \& Hubbard (2020) ${ }^{\text {ix }}$. From this standpoint, the long-term progress towards greater gender equality may derive largely from changes in social norms and prospects that can bring about an equitable division of labor within the household. The relevant literature, which discusses similar changes, claims that such a redistribution of household responsibilities is likely to have lasting effects on gender roles and the division of tasks. ${ }^{X}$

Writing about Arab-Muslim women during the Covid-19 crisis, Abu-Habib (2020) emphasizes the importance of women's inclusion and empowerment in Middle East societies:

There is no dearth of evidence at this stage in terms of the toll that the pandemic has taken on women and girls [...] What the pandemic has also shown us, yet again, is that "change is possible and necessary," and that there is no going back on women's and feminists' demands for rights, justice and inclusion.

Chang (2020) dealt with women's health during the pandemic in Taiwan. The article argues that women have been badly affected economically and socially. Nevertheless, in terms of disease occurrence and lethality, women fair better than men due to their "hormonal protection and superior immune systems." Women are also more prudent and respectful of 
the preventive health measures like mask-wearing, social distancing and hand-washing more than men, which critically decreases the chance of infection. For the author, a gender perspective is highly needed in order to understand the various predicaments endured by women during the pandemic.

A survey conducted in Gauteng, South Africa by Parket et al. (2020), revealed how that "net job losses were higher for women than for men", and women have spent more time on childcare since the start of the lockdown. The study also showed that women were at more risk because they did frontline care and service work and were in daily contact with many people. ${ }^{\mathrm{xi}}$

In this article, I use insights from the current literature with data on the distribution of women, men and couples, according to occupation and time-use in the division of tasks. This will help us shed some light on how the Covid-19 pandemic has affected women and gender relations. The article emphasizes that the short-term problems caused by the crisis are severe, especially for women in the informal sector, mothers, the elderly, and all lowincome families. The article contextualizes the Covid-19 crisis in Morocco with emphasis on the ways in which this global catastrophe has worsened and intensified existing gender and social inequalities, whilst at the same time opening new horizons for creative and substantial feminist engagement.

The information used in this article is equally based on my knowledge and contacts with feminist networks, my own publications, as well as on the research undertaken by local and international academics, and official government reports. I argue that looking at the Covid-19 crisis through a gender lens can only be possible if we are acquainted with the situation of gender relations and women's status in the region and the feminist movement around it prior to the pandemic.

\section{Understanding the context of gender relations in Morocco}

Morocco is basically a patriarchal society where the laws codifying gender relations are based fundamentally on the supremacy of the male head of the family considered the main provider and decision maker. Women's lives, choices, and mobility are controlled by the male members of their families. This has meant that, for several decades, women's lives in Morocco and other North African and Middle Eastern (MENA) countries have been subdued and oppressed, whilst outdated habits and customs have been maintained in order to limit women's freedom and emancipation, especially in terms of their choices and decisions. Despite progress made at closing the gender gap in education, women have yet to attain decision-making positions, whether in the private or the public sphere (Abu-Habib, 2020; Ennaji, 2018; Sadiqi \& Ennaji, 2006).

Since the independence of Morocco from France in 1956, different political parties and civil society organizations have demanded reforms of the family and electoral laws in order to improve the rights and status of women and their participation in public life. The monarchy has played a determining role in the enactment and implementation of a wide range of changes. For example, the personal status law, Mudawana, has experienced two major milestone reforms since it was established 1957.

The first reforms took place in 1993, but they were minor as they only slightly restricted polygamy and required women's consent for the marriage to occur. Custody was given to the mother, but in case of the mother's remarriage, custody was given to the father or to the maternal grandmother instead of the mother. In spite of their disappointment, liberal feminists considered the 1993 changes symbolically immense because they made the debate on the Mudawana public for the first time in the history of Morocco, a sign that the Moroccan feminist movement was making significant headway. Indeed, the biggest success of this movement was its ability to bring an almost 'sacred' religious text into the heart of public debate (see Ennaji \& Sadiqi, 2012).

After a decade of debate and advocacy, the family code was substantially amended in 2004, which allowed women to freely marry at the age of 18 whoever they wished (without the guardianship of the father) and put both marriage and divorce in the hands of the family court. Furthermore, the Mudawana has had a positive upshot not only on the personal and the family spaces but also on the public field. Women's organizations, which gathered one 
million signatures in favor of the reform, were actively involved in the struggle and the national debate which resulted into the espousal of the milestone Mudawana (see section below on women's activism, and Zoglin (2009) and Ennaji and Sadiqi (2012) for a historical background of the family code reform).

The public opinion was enthusiastically involved in debates and conversations concerning these reforms and new laws (Ennaji and Sadiqi, 2012; Zoglin, 2009). Progressive political parties described the Mudawana as a vital building block in the development and democratization processes. This much fought-for reform irrefutably constitutes a new accomplishment, not only for the feminist movement, but also for democratic progressive men who believe in gender equity and equal rights and responsibilities. Moroccan women's legal status and daily life have been transformed over the last two decades; the legal, political, social, and educational achievements have been outstanding and valuable to the entire country. However, Morocco is still behind according to the gender equality index, where it is ranked, 143 out of 153. ${ }^{\mathrm{xii}}$

The recent adoption of electoral gender quotas in North Africa, particularly in Morocco and Tunisia, with the aim to rapidly increase the seats allotted to women, has had a positive impact on neighbouring countries like Algeria and Libya, which have also lately adopted the quota system, as more and more women are involved in electoral processes and in political power. Political parties have themselves taken measures for gender quotas monitoring the gender dimension of their candidate lists (Ennaji, 2015).

Although the quota system is helpful to women, as it allows them to reach parliament without going through the high financial cost of election campaigns, intimidation, and harassment, it is harder to change mentalities and eliminate prejudice against them (Darhour \& Dahlerup, 2013). In Morocco, 305 of the 395 members of the lower house are elected in 92 constituencies through a proportional representation system. An additional 60 seats are reserved for women, while 30 are reserved for young men under the age of 40 . The reserved seats for women are filled by those elected through a proportional representation system based on nation-wide closed-party lists (Article 23-2 of the Organic Law 27-11 on the House of Representatives). xiii This system, legislated through the 2011 electoral reforms, builds upon the previous 'honorary agreement' between the political parties, formed in 2002, which reserved 30 percent of seats for women. (Ennaji, 2015; Darhour \& Dahlerup, 2013).

Women play a crucial role in socio-economic development despite the existence of large inequalities between men and women so far as access to resources is concerned. A considerable proportion of women in Morocco are active in jobs related to the public and private sectors. In the formal sector, women are active in the public domain and in social services. The rate of women working in both the public and private sectors is low. Out of the 12.2 million workforce in Morocco in the fourth quarter of 2019, 70.5 percent were men and 22.1 percent were women. While a high percentage of active men and women lived in rural areas as opposed to urban areas, the active population gender gap remained wide for the two genders, as we shall elaborate below. ${ }^{\text {xiv }}$

Non-government organizations (NGOs) have recently taken the lead by stepping in to encourage women to fully partake in public life and to mobilize society as a whole to women's role in democratization and development. Despite this important move, women have not benefited from a larger participation in public affairs and in decision-making. Although the State has declared its readiness to share power, it imposes conditions that specify which group or party it is ready to work with and which group it is not ready to tolerate.

As a case in point, it is worth mentioning the following most well-known women's organizations: I'Union de l'Action Feminine (UAF) and l'Organisation Démocratique des Femmes du Maroc (ADFM) founded in 1983 and 1985, respectively following the struggle movement for women's rights. The UAF is a non-profit organization that started as an informal women's group under the name of "March 8th Movement" in reference to International Women's Day that year. The group, which developed over the years into a movement for the promotion of women's rights in Morocco, became UAF in 1987. Since then, this NGO has been the driving force behind the efforts aimed at raising awareness among women, decision makers, and society as a whole. The UAF has consistently fought for women's mobilization and against discrimination and marginalization. It successfully organized several national advocacy campaigns, meetings, and conferences targeting 
women's grassroots associations, civil society organizations, parliament, and government to promote women's rights and increase their participation in civic and political life.

The action of the women's associations constantly reminds political leaders that the international context, where legal standards concerning women are applied, can no longer be ignored. International organizations and treaties have generally had a constructive impact, as they pushed the government to adopt the gender approach in its policies and measures and to pass and implement progressive laws and reforms in favor of women's rights and political participation. Organizations like the United Nations Development Program (UNDP) have repeatedly issued reports demonstrating the connection between economic decline and the oppression of women. Simply put, MENA countries will not succeed unless women are fully integrated into political and economic life. The Arab Human Development Report (UNDP 2019), stressed the urgency of including women in the processes of democratization and development. Although the report underlined the notable advancement made by many countries in the region over the past decade, it affirmed that the region did not progress as fast as comparable countries in other regions. The report states that women's empowerment and political participation is of paramount importance for democracy and development in the region. I, for one, can assert that no democracy can be realized without the full participation of women and without their political representation (Ennaji, 2015).

At the educational level, the soaring percentages of illiteracy amongst women are in the majority of cases composed of rural women. In spite of the considerable endeavors that have been made at the government and civil society levels to remedy this state of affairs, the rate of illiteracy among women is still very high (41.9 percent) ${ }^{\mathrm{xv}}$. In retrospect, it seems that another vector of discrimination against rural women is the Moroccan educational system, which still favors urban areas over rural ones. Indeed, generalized education has not systematically fostered equality between urban and rural women and between men and women. Even in urban areas, girls are generally encouraged to opt for the least prestigious disciplines or for the ones that lead to the least available professional prospects, and dropping out of school is considered less problematic for girls than it is for boys, because they can always find a husband who can provide for them (Ennaji, 2008).

As mentioned earlier, the last two decades have seen significant legal reforms fought for by women and feminist activists. They culminated in changes in family codes, as is the case for Algeria, Egypt and Morocco, as well as the enactment of laws to protect women from all forms of violence in the private and public spheres (Abu-Habib, 2020; Ennaji, 2011). One of the major advances of the feminist movement has been politicizing gender issues as political matters which are debated within government and non-government institutions.

It is in this context that the Covid-19 pandemic has hit the region and exposed the sharp inequalities which feminist movements have been denouncing, as stated above. The shortterm and long-term effects of this crisis have been disproportionate on the level of gender, deepening social and gender inequalities. Before going into the discussion of my findings, I will first outline Morocco's economy and how the country has responded to the pandemic.

\section{Morocco's economy and the response to the pandemic}

\section{Economic background}

Morocco is located at a global crossroads of markets, development plans, and of ideas; it has experienced transformation not only in the organization of its market and policies, but also in the more profound issues of political identity and social structure. Despite the recent efforts of government and civil society to modernize the country and promote women, the challenges facing women and development remain significant.

Being at the crossroads of Africa and Europe, Morocco covers a surface of 750,000 square kilometers for a population of over 36 million people. .vi $^{\text {Its }}$ urban population is estimated at 63.4 percent while the rural one represents 36.6 percent. Rural exodus has had a great impact since the 1960s when the rural population was estimated at 75 percent. ${ }^{\text {xii }}$

The economy is dominated by agriculture, followed by phosphates, tourism, and the remittances of Moroccan workers abroad. Agriculture represents 49 percent in the Gross National Product, tourism 19 percent, industry 17 percent and services 34 percent. xviii Since 1983, Morocco has engaged in a large structural adjustment program to clean and improve 
the economic environment. This program has had a positive impact on the macro-economy, but some bad consequences on the micro-economic level: increase of unemployment (16 percent), stagnation of salaries, low level of education and health services (Ennaji, 2018; Friedman, 2010).

On the whole, economic adjustment reforms and privatization have had negative effects on working-class and lower-middle-class women. These reforms seriously undermined their economic and social well-being as a consequence of the high rate of unemployment among women. Many have to delay their marriage plans for lack of an income or to accept separation from their unemployed husbands who are unable to cater for their families.

As stated above, women play a crucial role in socio-economic development despite the fact that there exist large inequalities between men and women so far as access to resources is concerned. In rural areas, which are marked by labor and gender division between men and women, women have growing responsibilities in ensuring the survival and well-being of the family, and in doing their share of farming and of production, small trade, and services.

In the informal economy, which represents about 50 percent of the national economy, women are active mainly in small trade social services. The economic reforms, which were implemented since the 1990s as a result of the adoption of the structural readjustment, which fostered economic liberalization and free trade, led to a reduction of State feminism. The relative retreat of the State from the economic scene as the main agent of change undermined its commitment to gender equality. In general, it is working-class women who have suffered most from these unfair economic and social reforms (Ennaji, 2006).

On the whole, economic structural adjustments and liberalization were neither accompanied by a greater emancipation of women nor by gender equity. Rather, they have introduced changes that reinforced gender inequality at the economic and political levels, which enhanced women's dependence on the State to protect their rights and foster their participation in active life.

Privatization and inflation pushed many women to join the work force. Hence, the feminization of the labor force which began in the 1970s and developed in the 1990s manifested itself in the public sector, industries and services. Since 1990, women became attracted to the private sector, which generally offered them relatively stable employment although it did not guarantee social benefits like maternity leave, health care, and transportation (Ennaji, 2006).

The government has failed to address effectively the social and gender inequalities, as it did not take the necessary action which would have probably improved people's lives and put them in a strong position to fight the pandemic. Thus, the phenomenon of exclusion is noticeable in the rural areas and in the poor urban districts, and in the growing number of beggars amongst women (generally widows, divorced women, sick women, handicapped women, or women with many children). The Moroccan government has recently launched a campaign to fight against poverty and illiteracy among rural women, which had a great impact on the women's welfare and people's attitudes in general (Sadiqi, 2016).

\section{How Morocco responded to Covid-19}

Morocco is by no means exempt from the macro-economic fallout from Covid-19. According to the Moroccan High Commission for Planning (HCP), all economic indicators show markedly declining forecast levels which, presumably, are likely to deteriorate even more in 2021. ${ }^{\text {xix }}$ The Moroccan Conjuncture Center (CMC) does not rule out that the economic situation may deteriorate even further if the pandemic persists. ${ }^{x x}$

Before the pandemic broke out, the country was already experiencing important economic and political problems, including a rundown healthcare system. In Morocco, the health budget currently represents some 5 percent of the national budget, against the 12 percent recommended by the World Health Organization (WHO), and the health system remains marked by "deep geographic and socioeconomic inequalities", according to the WHO. ${ }^{\mathrm{xi}}$

Real GDP is projected to contract by 6.3 percent in 2020 , primarily due to the pandemic but also to a severe drought. In turn, the fiscal deficit is projected to widen to 7.6 percent of GDP which, combined with the recession, will provoke a substantial upsurge in the debt-toGDP ratio. Lastly, the decrease in exports, tourism revenues, and remittances of Moroccans abroad may increase the existing account deficit to 9.9 percent of GDP. As in the rest of the world, the Moroccan economy is expected to bounce in 2021, which will help improve the 
budget and reduce current account deficits. However, the pace of recovery depends on the evolution of the pandemic and the future rebounding of Morocco's main trading partners. ${ }^{\mathrm{x} i \mathrm{i}}$

With the Covid-19 pandemic, Morocco is experiencing the most severe health, economic, and social crisis since its independence in 1956. Unemployment has skyrocketed to over 12 percent according to official figures. It is higher among young people aged between 15 and 24 (33.4 percent), university graduates (18.2 percent) and women (15.6 percent). ${ }^{\text {xxii }}$ To the inequalities in terms of employment are added the inequalities in working conditions that the pandemic has exposed and amplified: public functionaries and private sector managers, who are more spared by the crisis, have massively teleworked, while manual workers and employees are almost always on site where exposure to infection is greatest. Remote work, and the flexibility of working hours that goes with it, are mainly associated with business managers and executives for whom the rise of digital technologies has led to a major change in the way they work.

Recognizing the vulnerability of its strained healthcare system, the government has been proactive, closing airports, ports, borders, restricting travel, closing schools, cafes, mosques, establishing stay at home orders and setting up curfews (from March to June 2020 and again from December 23, 2020 to January 30, 2021). While in normal times, these would be considered extreme measures, they too often now seem necessary although temporary actions to halt the spread of the pandemic. The curfew lasted from nine at night until six in the morning; public and private parties and gatherings were banned, and restaurants and non-essential shops were closed, starting from eight in the evening. ${ }^{\text {xxiv }}$

Understandably, there is concern about both the short and long-term socio-economic devastating consequences and about broader stability impacts of the virus in the coming years. Of all people working in the private sector or the informal economy- which represents more than 42 percent of the country's GDP (Othmane and Mama, 2016) - , who were employed on March 1, 2020, over one million people lost their jobs four months later. ${ }^{x \times v}$ The economy has suffered a sharp decline by 53 percent at the national level. The crisis has hit mainly the tourism industry (63 percent), services (54 percent), and agriculture (41 percent). ${ }^{x x v i}$ The shocks to supply and demand prompted by the Covid-19 pandemic have been amplified by the underperformance of the agricultural domain as a consequence of a dry winter. In this context, in 2020 the unemployment rate increased from 8.1 percent to 12.3 percent. The Moroccan government has implemented important policies to alleviate the bearing of these shockwaves on families and businesses, as well as transfers to formal and informal workers; allotting partial guarantees to banks for loans contracted to firms; a decrease in the Central Bank's benchmark interest rate by 75 basis points (to a historically low 1.5 percent); and direct injections of liquidity into the financial structure.

The pandemic has exacerbated Morocco's recession, thus swelling the country's financing needs. The fiscal endeavors, which were made by the government in recent years, have been stopped as expenditure on health and social protection has had to be enlarged considerably to respond to the crisis. A serious economic depression has resulted in a shortfall of tax revenues, mainly from customs duties, goods and services, income and profit, which will worsen the budget deficit. Furthermore, Morocco's liberal economy is extremely unprotected to international shocks and particularly to hostile developments in the Eurozone area. According to a recent World Bank report, during the first half of 2020, a severe reduction-in remittances (-8.1 percent), tourism (-33.2 percent), and exports (-18.3 percent)—has had an adversative effect on the country's existing account. ${ }^{\text {xvii }}$

Several Moroccan companies have prepared social plans to downsize up to a third of their workforce in order to ensure their survival. This is a reasonable approach, according to the employers, but it may put tens of thousands of people, all classes combined, in precariousness. The State must quickly find a solution. The Moroccan government has introduced several palliative measures in response to the Covid-19 crisis: i) Establishment of a zero-rate credit for self-employed entrepreneurs weakened by the crisis; ii) Exceptional accounting treatment to extend donations and charges relating to the period of the state of health emergency; iii) Softening of the declarations of employees affiliated with Moroccan Social Security (CNSS) who are on a temporary work stoppage. The total of the endowments, contributions, and participation would approach Moroccan Dirhams 37 billion (approximately $\$ 4$ billion); iv) Adoption of remote work and distance education as flexibility and prevention measures for the public and private sectors and the educational field. Economic recovery will require a lot of time, at least three years, and can only be gradual. It 
will likely be impossible without State support. Furthermore, the recovery will require the combined efforts of all actors in the public and private sectors. The key is solidarity among groups within society and between countries. .xviii

To address this unprecedented crisis, the Moroccan government has indicated that it will support vulnerable sectors and has begun compensating some of the most defenseless affected citizens. ${ }^{x x i x}$ The government encouraged the mobilization of the media and of the Ulema (theologians), preachers and imams to raise awareness on the prevention of COVID19. The collaboration of the theologians was key in the decision to close down mosques, which set a precedent and sent "a symbolic message to the population with regards to the gravity of the situation and the necessity to act responsibly." (Zaghloul, 2020)

At the end of July 2020, King Mohammed VI announced a new roadmap to boost recovery and spur inclusive growth, inviting the government to develop a plan to meet its objectives, including: health care for all the population within a 5-year timeframe; the expansion of social welfare to vulnerable segments of the population; the reform of state-owned companies; and strong measures to boost economic recovery, including the setting up of a strategic investment fund worth $\$ 4.8$ billion to help businesses and individuals recover from the Covid19 crisis. On August 4, the government unveiled a detailed plan to address these priorities (Zaghloul, 2020).

To help Morocco cope with the negative impact of Covid-19, the World Bank restructured, in April 2020, a \$275 million Disaster Risk Management Development Policy Loan, with a Catastrophe Deferred Drawdown Option (Cat DDO). This added a health-related trigger to allow immediate funding for emergency measures. In addition, in June 2020, the World Bank granted a $\$ 48$ million loan to back the government public health system's response to the pandemic by consolidating measures of prevention for infection, as well as its detection, surveillance, and case management. ${ }^{\mathrm{xx}}$

In response to the health crisis, in May 2020 the Ministry of Solidarity, Social Development, Equality and Family, in partnership with the Social Development Agency, developed an online marketplace, called ADS Coopsclub, to sell the cooperatives' products during the health crisis. This platform was intended to include all women's cooperatives in Morocco. UN Women supported cooperatives like Tudert and Ariaf to join the online marketplace by helping with administrative processes such as online registration. An online awareness and information session on hygiene protocols and physical distancing measures were also led by UN Women as part of this initiative. "At the beginning of the crisis, with the weekly regional markets closed in Imi N'Tlit, it was very difficult for us to find a solution to sell our products," said Aicha Ennaih, a member of the Tudert Cooperative. "When UN Women informed us about this platform, it was great news for our cooperative. We were able to register and to negotiate product delivery fees with service providers, allowing us to take advantage of this unique opportunity at a good cost," she concluded. ${ }^{x \times x i}$ Leila Rhiwi, Representative of the UN Women in Morocco affirmed that while the Covid-19 pandemic aggravated inequalities and vulnerabilities, it also showed that women were agents of change who could respond to this disastrous health crisis. UN Women supported cooperatives such as Tudert and Ariaf by providing technical assistance to help them lessen the impact of the pandemic on their revenues. ${ }^{x x x i i}$

But under what conditions did the Moroccans continue to work, according to their gender and their socio-professional category? We will attempt to answer this question in the following section.

\section{Impact on women and gender relations}

The cessation of professional activity, combined with the closure of schools had varying effects on families and gender relations. On the one hand, the time freed up could increase parenting time and help improve relationships in the short term; on the other hand, the decline in household income - which very often accompanies the cessation of activity - could deteriorate, in the longer term, the relationship with spouses and children and increase the feeling of isolation of households.

The Covid-19 crisis seems to have affected first and foremost the less educated and the precarious, as in every severe recession. Performed in a new normal, continuous teleworking is developing massively for white collar employees and executives, without housing being always adapted. However, for women the situation is more difficult. The pandemic and the 
economic crisis it has engendered are widening the social gaps with men, after three decades of endeavors to reduce gender inequalities. Thus, the Covid-19 pandemic has revealed and exacerbated the deep divisions that cross Moroccan society in terms of gender roles, employment and working conditions. The indicators are deteriorating and the gaps are widening between the genders and social classes.

Moreover, the overrepresentation of women in frontline jobs, such as health care services, overexposes them to the new Coronavirus and substantially increases the risk of infection and the risk of contamination at home, as indicated by the official statistics department. According to the HCP, women represent 58 percent of medical workforce and 67 percent of paramedical personnel (nurses and technicians). Since its implementation, the lockdown strongly reduced women's access to health care. As efforts focus on limiting the spread of the virus, essential services such as access to reproductive health facilities have been disrupted. Among women eligible for prenatal and postnatal consultation services, 30 percent had to give up these services during the sanitary lockdown. ${ }^{\text {xxxiii }}$

\section{Violence against women}

A study by HCP revealed the rise of violence against women and girls during the pandemic, as one in four women suffered from physical violence. ${ }^{x x i v}$ It found that violence against women could have serious health consequences for the victims' physical, moral, and social well-being. ${ }^{x x y v}$ As to domestic violence, according to HCP, 25 percent of Moroccans have experienced conflict situations with the people with whom they have been confined, due to tense gender social relations during the lockdown. Among the causes, we can cite child rearing. More than 12 percent of parents of school-age children report having had marital disputes because of the children's learning issue. The proportion reaches 14 percent among city dwellers and 9 percent among rural people (Allouche, 2020).

Almost one in five Moroccans (18.6 percent), 20.3 percent among women and 17.2 percent among men, argue with their spouse about the education of children outside their school support (behavior with children, time allocated to children, time spent by children in front of screens, etc.). Over 59 percent of them report that this conflict has happened several times before. In addition, the financial aspect is also a source of tension between spouses. In this regard, more than one in five Moroccans (22 percent) have quarreled, two thirds of respondents affirmed that was more than usual. The highest shares are recorded among young people under 24 (28 percent), the unemployed (26 percent), couples with children (26 percent) and rural people (25.4 percent). Finally, more than 8.4 percent of Moroccans report having had marital disputes over the sharing of household chores within the couple, including 63 percent of cases more than before. .xxvi

Confined women victims of domestic violence are marooned with their violent partners. A situation which calls for vigilance and which requires the intervention of associations combating violence against women. Stéphanie William Bordat, co-founder of the association Mobilizing for Rights Associates (MRA), shares her concern: "Isolation creates pressure which, in addition to current economic tensions, increases the vulnerability of women. They are deprived of the possibility of fleeing. We expect violence against women to increase."xxxvii

In addition, HCP points out that women and men are exposed differently to the psychological effects of Covid-19. If, according to the household survey, the main consequences are sleep disorders, anxiety, fear, and obsessive behavior, it should be noted that women heads of households appear to be more affected by this psychological distress than men. This crisis also seems to have made households headed by women more precarious, with little access to health care. ${ }^{\text {xxxviii }}$

A report by the Association for Women's Rights underscores the forms of violence that Moroccan women have been subjected to during the lockdown period, as psychological violence remains predominant, and husbands remain the first perpetrators of violence. More than 57 percent of women nationwide reported having experienced a form of violence since the pandemic broke out. ${ }^{\text {xxix }}$ The report presents statistics related to the phenomenon of violence against women and girls in quarantine, during the period between last March 16 and July 10 , as the association set up a platform to listen to battered women with the aim of receiving women's complaints from various regions of Morocco. These incidents increased steadily throughout the lockdown period. The report noted that the quarantine conditions made all components of the family, including men and women, share the same space all day, seven days a week, and thus women and girls became constantly victims of domestic violence. The increase in violence reveals the nature of a patriarchal society and the 
authority of males, as economic providers, and the quarantine made men cast their anger and violence on women and girls.

The HCP report mentioned the government's failure to invoke the gender approach in providing support extracted from the Corona Pandemic Management Fund for families, which ranges between 800 and 1200 dirhams, depending on the number of family members, indicating that most women do not have a universal "Ramid" health care card, and are not affiliated with the National Social Security Fund, Consequently, it is men who draw support, which increases the vulnerability of women and girls. Thus, the high rate of domestic violence during the lockdown poses many challenges related, on the one hand, to the Anti-Violence Law 103-13 and the measures it contains in order to protect victims and preclude them from violence that haunts them in a space in which women are normally supposed to enjoy safety and security.

\section{Teleworking}

Moreover, soon after the lockdown in mid-March 2020, there was massive recourse to teleworking ${ }^{\times 1}$, which has, however, harmed intrafamily relations. This is what the fieldwork reveals, which captures the new face of work and employment during the pandemic. Whether in terms of employment or working conditions, public sector functionaries and private sector managers appear to be more spared from the crisis than all other social categories. Most of them continued their professional activity during the confinement, working from home. Informal economy workers, private sector employees, and workers appear to be the most hit by the crisis, as nearly half of them lost their income by the end of December 2020, as mentioned above.

Strongly linked to one's occupation, higher diplomas appear to protect against the interruption of activity, in recession even more than in periods of growth. Most active people with a higher education degree kept their jobs during and after the lockdown, but only half employees with a high school certificate were able to keep their jobs (Allouche, 2020). The occupations, which were most active during the lockdown, were the administrative intermediary professions of the public service, the police and the military, public health workers (mainly nurses and doctors) administrators, bankers, and company executives. On the contrary, the professions which saw their activity drastically reduced were skilled and unskilled people, architects, lawyers, commercial workers, employees of direct services to individuals, hospitality workers, and taxi drivers.

The situation has deteriorated most markedly for women. Among those interviewed who were employed on March 1, 2020, only two in three continued to work three months later, compared to three in four men. Women worked from home as much as men; however, their conditions were different. The practice of teleworking in fact reveals deeper inequalities in living conditions, which unfold at home and in the private sphere. More often surrounded by children, teleworking women lived with one or more children at the time of lockdown, and they less often had a room of their own. By contrast, most male interviewees stated that they did not have to share their workspace with their children or other members of the household.

For families with children, domestic life is reorganized within the home due to new constraints, but also linked to the closure of schools and restriction of mobility. Where do children work in their homes? Do they have a room of their own? The differences between social groups are, from this point of view, significant. They reflect the disparities in living standards and housing conditions between households, but also the different educational standards according to social backgrounds. In the Fès region, having children study in an isolated room appears less common. According to the fieldwork, three households out of ten have their children study in an isolated room, against two out of ten in the periphery and rural areas.

By locking up households, the Covid-19 pandemic and the quarantine it imposed seem to have changed gender and family relations. While the majority of respondents did not observe any major change, more than a third of them stated that their relations with their families had deteriorated. There was more frustration, anger, and conflict in the families due to the lockdown, the anxiety, and the lower incomes caused by the pandemic. This was the case for those who had lost their jobs or those who had to work from home. The deterioration in relations with children appeared to be linked to the domestic and professional overload resulting from the pandemic. 
Thus, through the types of jobs held, social categories have been unequally exposed to these new family tensions. Working class people who often live in overcrowded apartments in appalling hygiene and sanitary conditions have to survive on a small income, and usually have to work daily outside their homes in order to earn a living. Further, they don't have the same resources to cope with the social pressures as middle- or upper-class people.

There are some positive aspects though. Despite less favorable housing conditions of manual workers and employees, an improvement of relations with their children appears to be more common, in particular for those whose professional activity has stopped. According to a recent report by HCP, 45 percent of men help with housework, with 19.3 percent of them saying they contribute to domestic work for the first time during the pandemic, compared to 13.1 percent in 2012 (Kasraoui, 2020). The report states that women allocate an average time of 4 hours and 27 minutes for housework on a daily basis, which represents six times the average time that men allocate by 45 minutes. According to this study, domestic work burdens women, regardless of their professional or social situation, as the time allocated to it is 3 hours and 54 minutes for active women, compared to 5 hours and 30 minutes for housewives. ${ }^{\text {li }}$ The lockdown, from this point of view, may have contributed to readjusting individual timetables for working-class families, in which working people are more often concerned with night work and atypical working hours.

On the contrary, a few white collar employees and executives report deterioration in relations with their children, and less often an improvement. The massive use of telework in this category may have contributed to unbalanced family relations. The domestic overload linked to new forms of telework, which is added to children's schoolwork, seems to be a game-changer in terms of the level of well-being of the various categories of the population.

There exist at least two ways through which the pandemic may hasten the evolution of social norms and expectations. The first one concerns the employers' level. Many companies are increasingly aware of their employees' childcare needs and are responding to them by adopting more flexible working hours and telecommuting choices. Through practice and evolving standards, some of these changes may become permanent. As a consequence, parents will need some fluidity to prerequisites of a career and raising a family. Since women are presently more perceptible to these competing demands, they will possibly benefit excessively.

The second way is related to social norms and patterns in families. While in many cases mothers will do much of the housework, childcare, and home schooling during the pandemic, there will still be a significant number of households where the patterns will be reversed. This is the case of female doctors, nurses, and pharmacy and supermarket personnel, whose husbands have been furloughed, lost their employment, or have been obliged to work from home. In these households, many men unavoidably help with the housework and with childcare, and home schooling.

For years, women working in the private and public sectors or in the informal economy have striven to achieve work-life balance, juggling professional practice and domestic responsibilities. Institutional logistic support for women, such as maternity leave, childcare facilities, lactation rooms, flexible working hours and nurseries, varies across institutions and cities. It is lacking in many areas across the country. The challenges that women face often stem from male dominated institutional culture, a real specter of illiteracy, as stated above, competing family responsibilities due to gendered domestic labor, and implicit and subconscious biases in recruitment and upgrades to decision-making positions. ${ }^{\text {xlii }}$

The Covid-19 pandemic and the consequent public health response of lockdown have brought into sharp relief the constraints faced by women across the board. Nowadays, career women are working from home, where they are also expected to take care of children and elderly parents, do home schooling, clean, cook, and shop (Lambert, et al., 2020).

I have observed the impact the pandemic is having on active working women. What I have noticed, and what's being backed up by this research, is that these women are facing additional constraints as a result of Covid-19. These range from the added burdens and responsibilities of working from home, through to the fact that fewer women have benefited from the government's aid, all the way to the large number of women who have lost their jobs or incomes, especially those in the private sector or in the informal economy. xliii

None of these constraints are new. Earlier research confirms that women in North Africa, more than men, suffer from poverty, unemployment, and illiteracy (Moghadam, 2012). 
Increased pressure on active women caused by the Covid-19 pandemic is magnifying this fractured landscape of gender. The impact is being felt in terms of health care, loss of income, or precariousness. This is manifesting itself in terms of the rising number of unemployed women and men with no income. The question to ask at this juncture is: What does the fieldwork I conducted bring to the table?

\section{Analysis of fieldwork results}

I interviewed forty people (twenty-five women and fifteen men), all of them married with children. Among them, there were eleven teachers, two nurses, a school director, a medical doctor, two journalists, a lawyer, an architect, an administrator, two housemaids, three graduate students, two merchants, two electricians, a secretary, a banker, a manager in the private sector, one executive, a bank employee, and a government functionary. Most of the interviews took place during spontaneous discussions. The age of the informants varied between 29 and 69, and the interviewees were all from the region of Fès, albeit from different socioeconomic backgrounds. To write this article, I also relied on previous publications on this topic, on official reports, newspaper articles, social media commentaries, and the experience of women in my surroundings. The social classes of the informants vary from working class to middle class.

The category most affected by the loss of income (tourist guides, traders, travel agents, small business people) more often than others report a deterioration of family relations, and less often an improvement. In addition, less than half of those respondents who have seen their household income decline since the start of the pandemic say they feel isolated and desperate. However, those experiencing a drop in income did not say they were more isolated than others before the start of the pandemic.

The fieldwork shows that working women increasingly bear the brunt of childcare tasks after the outbreak of the Coronavirus, and that they are also struggling to preserve their jobs in light of the consequences of the spread of this pandemic.

Four weeks after the lockdown in March 2020, Souad, a 32-year old teacher, had lost her job at a private school. She was under severe psychological pressure due to her desperate attempts to pay the bills. She was threatened by her landlord to leave the apartment if she could not pay for the rent. "It has been four months since my school has been shut down. I have been without pay since then. My anxiety and fatigue have reached the limit, and I am no longer able to do household tasks," says Souad.

Since the outbreak of the Coronavirus, her husband, who works for a law firm, started working from home, and they stopped sending their daughter to the nursery (as the government decided to shut all nurseries and schools throughout the country from March 16 until September 7) due to fears of the spread of the virus. But this situation has been frustrating for Souad, who shares home bills with her husband equally, and takes on the biggest burden of childcare, cooking and cleaning, while her husband spends most of the day in zoom meetings and video calls. The couple have decided to send their child to the nursery in mid-September 2020 and hire a maid for help to avoid disputes. Meanwhile, Souad is very busy with housework and childcare, with little help from her husband, during the peak of the pandemic, which has hindered her from finishing her Master's degree. "I couldn't allocate enough time to my thesis," says Souad. "I ran out of time because I am too busy doing several tasks."

Rahma, a 39-year old nurse, stated: "The lockdown changed our lives. For me, as a nurse, the pandemic has meant a twofold threat: the risk of catching the deadly virus in the hospital combined with the risk of being confined at home with an abusive husband." For Omar, a 43year old teacher, "the closure of schools and nurseries means many women teachers and social workers have not been able to report abuse because they feel vulnerable. In my own environment, cases of domestic violence are rising as households are tired of restrictions on mobility and of increasing poverty and economic adversity."

Jaafar, a 56-year old medical doctor testified: "because of the stay-at-home orders, there is an increase in violence and street harassment during the Coronavirus pandemic; girls and women do not feel safe on the street or at home." Ismail, a 62-year old lawyer, stated: "There is an increase of domestic violence against women aged between 18 and 55, especially since March due to the quarantine." 
Aicha, a 49-year company manager, mentioned how her 27-year old cousin was beaten up by her father every day for no good reason. "It was very bad. I could not stand seeing her being abused. I recorded a video of the scene and sent it by WhatsApp to my grandmother, who was very upset. She said: this is disgusting. A week later, we moved my cousin to her place until the end of the quarantine to get away from the violent father."

Loubna, a 37-year-old architect, had to leave her job in order to give birth to her second son. She gave birth at the end of March when the pandemic was sourly increasing. Her first son turned three. She needed help from her husband, a banker who was working from home. She said she endured months of symbolic and physical violence from her husband after she gave birth. He was stressed out by his own work and refused to change the diapers or wash the dishes. But after the confinement restrictions had been eased out in July, he tried to change since he last struck her. "He has apologized to me. Now he is becoming more helpful and supportive," she said.

Bouchra, a 47-year old secretary in a private business, lost her job after her company closed down. Her husband was very disappointed at the bad news. She had a negative view about her husband's reaction: "He started yelling at me, using a violent language. He went from refusing to help in the kitchen to being nasty and violent. He blamed me for what happened, saying he was unable to provide for the household on his own. He said it was my entire fault."

Only few professions have been spared by the health crisis. Domestic workers are not left out. While the situation of workers responsible for cleaning and disinfecting offices remains stable, domestic staff is always dependent on the goodwill of employers, some of whom have not hesitated to dismiss their personnel overnight. The example of Hayat, a housemaid who works for a family in Fès is a good case in point. She declares that she has given up seeing her own family in order to keep her job. "I cannot pay them a visit because there is also the risk of contracting the virus", she adds. The young cleaner, aged 48, describes her long working days since the outbreak of Covid-19 and explains that her workload has doubled since the start of lockdown. "There is no rest," she regrets. Especially since it is often very frowned upon that the domestic staff, whose recruitment continues to be done in the informal sector, requires vacations and social rights (Ennaji, 2011).

In this context of the health crisis, "families prefer single housemaids, who will agree to stay at home as long as the lockdown is still in force," Moussa, 43 a clerk and a recruiting agent operating in the informal sector told me. This situation may be explained, in part, by the fact that a number of employers, and business people are disappointed by the unexpected departure of their domestics who, on the eve of Eid El-Kébir (the main Muslim religious feast equivalent to Christmas in the Christian world) left, without warning, to join their families just before the government's decision to ban travel between certain cities.

Said Saadi, the former Minister of Social Development and Solidarity in the alternation government (1998-2000), said that women are more affected by the repercussions of the Covid-19 pandemic, compared to men, considering that "the current crisis is an opportunity to break with the neoliberal trends that have harmed gender equality." That "requires adopting a new approach, based on the concept of a democratic, developmental, and a socially just state." (See Lambert, et al., 2020). Said Saadi added, on the sidelines of an online conversation: "The existing development model is at the test of this health crisis: Let us make the crisis our opportunity to advance equality between women and men."

For his part, Douiyeb, a 27-year old human rights activist and doctoral student researching issues of governance, said that the development model in Morocco had produced disastrous results at the economic and social levels, "and this is confirmed during the health crisis caused by the Covid-19 pandemic, as it has produced greater vulnerability in priority sectors. We need a development model based on the foundations of dignity, social justice, fairness, and equality".

In the same vein, Fatima Sadiqi, researcher and president of the Association for Women and Development, in the city of Fès, informed me that "women "find it more difficult to use modern technologies than men, due to the high rate of illiteracy among them, firstly, and secondly due to the high material cost in many cases." On the other hand, she added that digitalization allowed women to have access to information, possibilities of communication, and freedom of expression; it has also provided women's movements with the opportunity to network and include new and activists, and to highlight new relevant issues, which had been usually marginalized or absent from public debate. 
Table 1: Demographic characteristics of interviewed individuals (only their first names or last names have been used to preserve their anonymity)

\begin{tabular}{|c|c|c|c|c|}
\hline Answerer & Gender & Age & Level of education & Profession \\
\hline Souad & $\mathrm{F}$ & 32 & University graduate & Teacher \\
\hline Rahma & $\mathrm{F}$ & 39 & High school & Nurse \\
\hline Omar & M & 43 & University graduate & Teacher \\
\hline Jaafar & M & 56 & Medical school graduate & Doctor \\
\hline Ismail & M & 62 & Law school graduate & Lawyer \\
\hline Aicha & $\mathrm{F}$ & 49 & University graduate & Company manager \\
\hline Loubna & $\mathrm{F}$ & 37 & University graduate & Architect \\
\hline Bouchra & $\mathrm{F}$ & 47 & High school & Secretary \\
\hline Hayat & $\mathrm{F}$ & 48 & Primary & Housemaid \\
\hline Yassine & M & 37 & University graduate & Banker \\
\hline Saadi & $\mathrm{M}$ & 69 & University & Teacher \\
\hline Sadiqi & $\mathrm{F}$ & 66 & University & Teacher \\
\hline Latifa & $\mathrm{F}$ & 43 & University & NGO director \\
\hline Samira & $\mathrm{F}$ & 42 & University & NGO manager \\
\hline Nadia & $\mathrm{F}$ & 52 & University & School director \\
\hline Fadwa & $\mathrm{F}$ & 35 & University & NGO activist \\
\hline Rajaa & $\mathrm{F}$ & 48 & University & Administrator \\
\hline Rafika & $\mathrm{F}$ & 51 & University & Bank Employee \\
\hline Aboubakr & $\mathrm{M}$ & 36 & University & Teacher \\
\hline Zhor & $\mathrm{F}$ & 42 & Primary & Housemaid \\
\hline Ahmed & M & 47 & University & School director \\
\hline Oussama & $\mathrm{M}$ & 32 & High school & Electrician \\
\hline Fatima & $\mathrm{F}$ & 39 & University & Teacher \\
\hline Zahia & $\mathrm{F}$ & 45 & University & $\begin{array}{l}\text { Government } \\
\text { functionary }\end{array}$ \\
\hline Hassania & $\mathrm{F}$ & 26 & University & Graduate student \\
\hline Bouchta & $\mathrm{F}$ & 36 & University & Teacher \\
\hline Jamila & $\mathrm{F}$ & 28 & University & Graduate student \\
\hline Fouzia & $\mathrm{F}$ & 45 & University & Teacher \\
\hline Issa & $M$ & 49 & University & Executive \\
\hline Amina & $\mathrm{F}$ & 29 & University & Graduate student \\
\hline Oulfa & $\mathrm{F}$ & 42 & University & Teacher \\
\hline $\begin{array}{l}\text { Abderrahma } \\
\mathrm{n}\end{array}$ & M & 47 & High school & Merchant \\
\hline Amine & M & 38 & High school & Electrician \\
\hline Hakima & $\mathrm{F}$ & 39 & University & Teacher \\
\hline Rabiaa & $\mathrm{F}$ & 35 & University & Teacher \\
\hline Hamida & $\mathrm{F}$ & 42 & High school & Nurse \\
\hline Ahmed & M & 47 & University & Merchant \\
\hline Zaki & M & 32 & University & Journalist \\
\hline Halim & $\mathrm{M}$ & 39 & University & Teacher \\
\hline Abdelaziz & $\mathrm{M}$ & 35 & University & Journalist \\
\hline
\end{tabular}


Despite the easing of quarantine measures since last July, some activists and women's rights advocates believe that the pandemic will have long-term effects on women's work and their family lives. xliv $^{-}$

Latifa Bouchoui, President of the Federation of Women's Rights Association, said in a statement that "all the conditions during quarantine confirm that women are more vulnerable to mental disorders, and this has been proven through the Federation's tracking of the conditions of this group," noting that what exacerbated the situation further was the lack of access to material support, which benefited mostly men. Among the measures that human rights actors call for is the need for psychological follow-up of women as well as men, the improvement of economic and social standards, and the provision of support by various government institutions

For her part, Samira, a 42-year old manager of the same association, spoke about the fact that psychological pressure among housewives has been aggravated by the measures that have been taken to limit the spread of the epidemic, saying that "the situation has worsened among women in general and not only housewives, given that the lockdown obliges working women to stay at home." She added: "The measures taken have put pressure on large families, not to mention the fact that the lack of space creates promiscuity, in addition to lack of hygiene and sanitation."

Rafika, a 51-year lawyer, described the life that a number of marginalized Moroccan women live inside crowded homes during the quarantine, with the violence that affects them inside, as "hell", and said that "women are subjected to various forms of violence, ranging from physical and psychological, and deprivation of spending to death threats." Nadia, a 52year reporter, stated that "when a journalist is familiar with the human rights aspects of sexual assault cases, s/he can contribute through articles and investigations to changing mentalities and shedding light on important issues in this aspect." Fadwa, a 35-year old civil and human rights activist, mentioned that "social media provided an opportunity to express opinions, dialogue, and exchange information," adding that "women, despite the apparent freedom granted by social media, increasingly complain about the threat to their right to freedom of expression through communication platforms."

Rajaa, a 48-year old administrator, explained that this threat is particularly evident in the spread of violence and abuse of women through sometimes organized campaigns against topics of concern to women, stating: "We recently saw how wild campaigns were launched against working women that went so far as to describe every working woman as a prostitute."

She highlighted that people of all gender groups could be exposed to violence and abuse on the Internet, and that "the abuse that women are subjected to is often of a sexual or gender-biased nature, and threats of violence against women on the Internet are often sexual and include specific references to their bodies."

Many women also exercise self-censorship on their thoughts and attitudes because they are certain that the extent of the harm that they may suffer as a result of expressing an opinion or attitude may engender physical violence. These threats in some cases lead them to completely distance themselves from social media platforms. Therefore, the harassment that women are subjected to takes many forms, including the violation of privacy, extortion and threats to publish private or intimate images of women in order to harm them, which creates a hostile atmosphere and constitutes a threat to women's safety.

The fieldwork results have provided the opportunity to witness how Covid-19 has exposed structural gender and social inequalities. As Intersectionality theory predicts, the epidemic has hit hard poor and unprivileged women and all those who are among the most marginalized demographic intersections: rural, single, divorced or widowed and workingclass people. ${ }^{x \mid v}$ Poor women are less likely to access to social security and protection. Covid19 has had a disproportionate impact on this underprivileged category, and women's organizations have issued ominous warnings about the pandemic's disastrous consequences in poor rural communities.

In the following section, I will provide a number of recommendations, making an appeal to decision-makers and civil society leaders to initiate reforms, new laws, and actions capable of empowering women and eradicating all forms of violence against them. 


\section{Recommendations}

The first recommendation that can be made from a feminist perspective is the recognition and valuing of women's care work as the foundation of the post-Covid economy through redistributing this load within families and also through adequate State policies. It is an economic approach that "recognizes the importance of care work in both the private sphere and the public sphere and treats it as work deserving proper compensation, protection, benefits and rights." (Abu-Habib, 2020). The post pandemic economy that is based on the recognition and valuing of women's care work is also one that operates beyond the exclusive gender binary. Women have proven that they have been at the forefront of the fight against the pandemic, that their rights should be protected, and that societies cannot advance while there exist social and gender inequalities (Abouzzouhor, 2020).

To attain this goal, the article emphasizes the following three priorities: i) ensure a gender approach at all levels, and guarantee women's equal representation in any Covid-19 response policy and decision-making, ii) address the care economy, paid and unpaid, in order to achieve transformative change, and iii) focus on women and girls in all endeavors to alleviate the socio-economic negative effects of the pandemic.

In addition, the State, private sector, and civil society must promote UN Sustainable Development Goals (SDGs) in order to change the post-pandemic world into a gender equal one. It is of paramount importance to establish gender-responsive disaster management, humanitarian response strategies and institutions, which integrate women's needs and perspectives in all domains. This approach will promote women's economic participation and empowerment for and through a gender-responsive national economic innovation, which fosters women's skills, contributions, and leadership in all domains. This includes rebuilding infrastructure, services, green production, and consumption.

The second recommendation addresses the technological empowerment of women and girls to benefit from and contribute to an equitable new normal of an accelerated fourth industrial revolution and digitized world. Governance and investment must close digital and technology gender gaps.

The third concerns universal access to affordable health care for all women and girlsSDG-4. Expanded health, medical, and pharmaceutical services should systematically serve women and girls' health care needs, chiefly reproductive health.

The fourth recommendation endorses a reformed and inclusive education system which can enable women and girls to achieve SDG-4. A quality accessible system of education can close the persisting literacy, numeracy, and education gender gaps (see Puri, 2020).

The fifth recommendation concerns a cultural and behavioral change at the individual and collective levels. SDG-5 must be the template for revamping and implementing postpandemic policies and laws and for embracing new social and cultural norms based on progressive global women's human rights norms.

The final recommendation is a call for the creation of support units for women victims of violence and their children in all police stations and directing them to immediately intervene to prevent violence, and to sue the abuser and providing them with adequate support to confront violence against women.

The pandemic response is an opportunity to rebuild society on an equal basis. It presents a chance to address the gender inequalities and make progress towards SDG-5 of gender equality. It is what the secretary general of the United Nations António Guterres termed the "pandemic of inequality around the world" from an intersectional feminist perspective. .lvi $^{\text {. }}$

Gender equality is a confirmed public good, and Morocco's gender equality dividend alone could add points to its GDP by 2025 . Additionally, the Covid-19 pandemic presents an opportunity to re-think gender equity, establishing the new development model on a more social conception of the economy so as to improve the sectors of public health and national education.

As we move beyond the immediate health crisis, policy-makers must seize the opportunity to implement bold, forward-looking reforms. This includes redesigning social contracts, providing adequate safety nets, cultivating the skills and jobs that the future economy will need, and improving risk management and the distribution of returns between the public, the State, and the private sector. 
If the Moroccan government is to take a leadership role, shaping the recovery and charting a new course for growth will require greater collaboration between businesses, the public, government institutions, and workers. For recovery to succeed, all stakeholders and citizens (women and men) must participate.

Right now, it should be obvious that we cannot go back to a system that benefits a few at the expense of the majority. Forced to manage short-term pressures and deal with long-term uncertainties at the same time, Morocco's leaders are at a historic crossroads. The new weight of the State gives it the means to start building a fairer, more sustainable, and more resilient economy.

\section{Conclusion}

Across every domain, from education, health, to the economy, from security to social protection, the effects of Covid-19 are exacerbated for women simply by virtue of their sex: The pandemic threatens the limited gains made by them in the past two decades. It is intensifying current inequalities, revealing vulnerabilities in social, political, and economic systems which are in turn swelling the effects of the health crisis.

The economic bearings are felt mainly by women and girls who are commonly making less money, holding insecure jobs, or enduring poverty. Unpaid care work has amplified, with children out-of-school, intensified care for older persons and overwhelmed hospitals. As the economic and social strain, coupled with restricted mobility and prevention measures linger, gender-based violence is growing rapidly. Women's socio-economic identities-race, religion, caste, age, class, multidimensional poverty, rural/urban and migrant status intersect, compounding gender discrimination (Intersectionality theory). Theoretically, intersectionality has proved to be relevant in describing and analyzing women's conditions and their struggle, and useful in highlighting and understanding the complexity of gender-based discriminations. Contemporary feminists in the region take into account the intersections of gender inequality and patriarchy in their discourse and knowledge production. Women's experiences are generally the product of intersecting models of sexism and male domination, and these experiences should also be taken into consideration by policy-makers. Addressing them holistically will have a force multiplier effect on women's rights. A universal social protection revolution based on a new social contract is key. The objective must be to leave no one no woman or girl behind.

The article has revealed that women and other marginalized groups bear the harshest and most disproportionate brunt of Covid-19, which has exacerbated structural social injustice and inequality at intersections of gender, status, class, as well as occupation. These are referred to by Intersectionality scholar Kimberlé Crenshaw as "specific and particular concerns." (Bowleg, 2020). Many of the riskiest and most stressful frontline jobs are underpaid and occupied by underprivileged women and men. These intersections contrast starkly with those of the predominantly white-collar and rich people.

Gender equality is acknowledged as a public virtue. It can exponentially increase the country's GDP. Hence it is vital that a gender equality approach is applied in the post pandemic era. One should also be aware of the need to reconsider the State's orderly disengagement policy, especially in the social sectors. It is important to opt for a new form of State interventionism, smarter and fairer, with better management of budgetary and fiscal instruments. It is also necessary to adopt more appropriate State regulation of the markets, without de facto monopolies and sometimes anti-competitive practices.

Finally, employment and income-generating activities should be encouraged, particularly for women (SDG-1). The health and economic crisis caused by the Covid-19 pandemic is a worldwide threat and a frank and esoteric break with current paradigms and models. The pandemic's unequal effect on the productivity and emancipation of women has the prospective to drain women from the public life. This will have a negative impact on women's participation in development and on diversity that is vital in politics and in civil society. To avoid this scenario, the country needs reforms of current laws and new policies to create optimum gender parity in public life. Anything less than these endeavors will perpetuate preCovid-19 levels of gender inequality and lack of diversity. The government should take measures to defend women's political participation during the pandemic and beyond.

Fiscal stimulus packages and emergency measures to address public health gaps have been put in place in many countries to mitigate the impacts of the pandemic. It is crucial that 
all national responses place women and girls at their center if they are to have the necessary results. This is not just about rectifying long-standing inequalities, but also about building a more just and resilient world. It is in the interests of not only women and girls but also boys and men. Women will be the hardest hit by this crisis but they will also be the backbone of recovery.

There are opposing forces which may eventually uphold gender equality in the labor market. Firstly, companies are fast adopting malleable work schedules, which are likely to persist. Second, many fathers now have to take primary responsibility for childcare, which may corrode old social norms that presently lead to an uneven distribution of the division of tasks in housework and childcare (Alon, et al., 2020)

The article has argued that, as with all large-scale crises and pandemics, while exacerbating inequalities and various forms of injustice, Covid-19 has also opened a range of opportunities for change. The article suggests that, whilst this window of opportunity may be short lived, it nonetheless brings massive opportunities for change in the lives of all women and men in the region.

To end on a more optimistic note, the pandemic denotes an opportunity to reimagine current models of governance, as well as the gender standards that reinforce them. Crises can stimulate new comportments, and periods of recovery create opportunities to lobby for policies that can change unfair gender norms and thus lead to more efficient governance systems. For example, as the health crisis leads public organizations as well as private sector employers to rethink how people work, advocates may be able to lobby for policies and practices that enable women and men to better share caring responsibilities, including more remote work options. Greater support for childcare and parental leave, and greater economic recognition of paid and unpaid care provision are sorely needed. These transformations must urgently reach parliaments, government authorities, and political parties, which often lag behind the private sector and civil society rather than lead the way. The pandemic is not only a challenge for global health systems, but also a test of our human spirit. Recovery must lead to a more equal world that is more resilient to future crises.

\section{Acknowledgment}

I would like to warmly thank for their constructive comments Sarah K. Cowan, Managing Editor of this Journal, and two anonymous reviewers.

\section{Footnotes}

iSee this report: https://www.reuters.com/article/us-health-coronavirus-africa-unidUSKBN21Z1LW (accessed on Sep. 10, 2020)

iSee John Hopkins University Center figures: https://coronavirus.jhu.edu/map.html (accessed on Dec. 29, 2020)

iiiFor Abouzzouhour (2020), the pandemic will have negative effects on the struggling economy and the political life. See the entire article:

https://pomeps.org/covid-in-the-maghreb-responses-and-impacts (accessed on Dec. 12, 2020)

ivEstimated by UNESCO, as of Mar. 25, 2020.

vSee their article. URL: https://www.thelancet.com/pdfs/journals/lancet/PIIS0140-

6736(20)31412-4.pdf (accessed on Dec. 19, 2020)

viSee this statement in its entirety: https://www.facebook.com/watch/?v=214704200145869 (accessed on Dec. 27, 2020)

viiln terms of mortality from the disease itself, it appears men are slightly more at risk than women. According to the Ministry of Health, 67 percent of inflected people are men. If current efforts to contain the spread of the epidemic are successful, however, many more people will be affected by the economic repercussions of the pandemic rather than the disease itself. For more figures, see this URL:

https://www.moroccoworldnews.com/2020/07/310706/ministry-of-health-launches-weeklybriefings-on-covid-19-in-morocco/ (accessed on Dec. 1, 2020) 
viiiSee, for example, Altonji, Kahn, and Speer (2016), Oreopoulos, von Wachter, and Heisz (2012), and Schwandt and von Wachter (2019).

ix See, for example, Kleven, Landais, and Søgaard (2019).

xSee for example Farré and González (2019) for evidence from Spain and for evidence from Tamm (2019) for Germany that paternity leave leads a persistent increase in fathers' involvement in childcare. However, Ekberg, Eriksson, and Friebel (2013) do not find an effect of "daddy months" in Sweden in father's likelihood to take medical leave to care for children.

${ }^{x i}$ Globally, more than 70 percent of healthcare workers are female, working as doctors, nurses, cleaners, ,etc.

See this link: https://theconversation.com/how-covid-19-puts-women-at-more-risk-than-menin-gauteng-south-africa-150570 (accessed on Dec. 21, 2020)

xiiSee this index on gender equality in all 153 countries. URL:

http://reports.weforum.org/global-gender-gap-report-2020/theglobal-gender-gap-index-2020/ (accessed on Dec.1, 2020). However, Morocco fairs better on the global governance forum. URL: https://globalgovernanceforum.org/wp-content/uploads/2020/11/Gender-EqualityandGovernance-Index-2020.5.pdf (accessed on Dec.1, 2020)

xiiiFor more information on the Moroccan House of Representatives, see this URL: http://www.maroc.ma/en/content/parliament (accessed on 22 May 2014).

xivSee link: https://www.statista.com/statistics/1174781/economically-active-population-inmorocco-by-gender/ (accessed on Dec., 2020)

${ }^{x v}$ This is according to official census of 2014. URL: https://www.hcp.ma/Note-d-informationdu-Haut-Commissariat-au-Plan-a-I-occasion-de-la-journee-internationale-de-Ialphabetisation-du-8_a2009.html (accessed on Aug 21, 2020)

xviThese are the figures provided by the Moroccan official statistics office: URL: https://www.hcp.ma/Projections-de-la-population-totale-du-Maroc-par-age-simple-et-sexe2014-2050_a2209.html (accessed on Dec; 12, 2020)

xviiSee this comparative report by the HCP: https://www.hcp.ma/Taux-d-urbanisation-en-parannee-1960-2050_a682.html (accessed on Dec. 12, 2020)

xviiiSource: World Bank: http://www.genderstats.worldbank.org

${ }^{x i x}$ For more figures, see this link: www.hcp.ma

${ }^{x}$ See more details in this report : https://cmconjoncture.com/conjoncture/actualites/politiquebudgetaire-le-cmc-pointe-du-doigt-le-manque-d-audace-de-l-executif (accessed on Sep.7, 2020)

${ }^{x x i}$ For more statistics, see this link: https://www.who.int/countries/mar/ (accessed on Dec. 12, 2020)

xxiisee this world bank report published on Oct. 1, 2020:

https://www.worldbank.org/en/country/morocco/overview (accessed on Dec 12, 2020)

xxiiisee more official figures in the website of the government's statistics department: https://www.hcp.ma/La-situation-du-marche-du-travail-au-deuxieme-trimestre-de2020_a2580.html (accessed on Sept. 2, 2020)

xxiv The government had taken a decision to completely close restaurants for three weeks in the cities of Casablanca, Marrakesh, Agadir, and Tangiers, at a period that was of particular importance for restaurants and nightclubs which are usually active in New Year's celebrations.

${ }^{x x v}$ More than 1.1 million were unemployed in Morocco at the end of 2019.

xxvisee note 3.

xxviiSource: https://www.worldbank.org/en/country/morocco/overview (accessed on Dec 12, 2020)

xxviii See more details in this piece: https://www.moroccoworldnews.com/2020/07/307656/thechallenges-of-post-covid-19-recovery-in-morocco/

xxix See my 2020 article on this issue :

https://www.moroccoworldnews.com/2020/05/302218/how-north-africa-is-responding-tocovid-19/

xxx See note 19. 
${ }^{x \times x}$ See this report by UN WOMEN:

https://www.unwomen.org/en/news/stories/2020/7/feature-covid-19-crisis-in-moroccodisrupts-value-chains-for-womens-cooperatives (accessed on Dec. 12. 2020)

xxxiiThe Tudert and Ariaf cooperatives received support from UN Women as part of an economic empowerment project funded by the Coca-Cola Foundation. The project aims to strengthen rural women's leadership while preserving biodiversity.

xxxiiiFor a comparative perspective, cf. this article on the impact of Covid-19 in Latin America: https://www.washingtonpost.com/world/the_americas/coronavirus-domesticviolence/2020/09/06/78c134de-ec7f-11ea-b4bc-3a2098fc73d4_story.html?hpid=hp_hp-moretop-stories-2_virusabuse-730pm\%3Ahomepage\%2Fstory-ans (accessed on Sep 7, 2020) xxxivSee HCP website: https://www.hcp.ma/Coronavirus-Pandemie-Covid-19_r22.html ((accessed on Sep 7, 2020)

${ }^{x \times x}$ According to HCP's study, more than half of victims of physical violence, 52.2 percent, reported sustaining scratches and bruises, while 11.2 percent sustained sprains and joint dislocation. The remaining victims reported serious injuries such as deep incisions, broken or cracked bones, or broken teeth.

xxxviSee this report realized by the Moroccan High Commission for Planning: https://www.hcp.ma/Rapports-sociaux-dans-le-contexte-de-la-pandemie-COVID19_a2577.html (accessed on Sep. 1, 2020)

xxxvii See this link : https://www.medias24.com/pendant-le-confinement-des-femmessurexposees-aux-violences-conjugales-9085.html (accessed on Sep. 7, 2020) xxxviii See this commentary :http://article19.ma/accueil/archives/132551 (accessed on Sep 6, 2020)

xxxix For more details and figures, see the full report : https://mrawomen.ma/wpcontent/uploads/doc/Coronaviolence\%20final\%20report\%20-\%20English.pdf (accessed on Sep. 1, 2020)

${ }^{x} \mathrm{I}$ use the words teleworking, home working and distance working interchangeably. At any rate, it is the alternative to working at the office which was prevalent before the pandemic.

xisee this report realized by the Moroccan High Commission for Planning: https://www.hcp.ma/Rapports-sociaux-dans-le-contexte-de-la-pandemie-COVID19_a2577.html (accessed on Sep. 1, 2020)

xlii Recent data from the US, the UK and Germany suggest women spend more time on pandemic-era childcare and home schooling than men do. This is particularly difficult for single-parent households, most of which are headed by women.

xliii See this link for more details : https://www.hcp.ma/L-indice-des-prix-a-la-consommationIPC-du-mois-de-Juillet-2020-Base-100-2017_a2583.html (accessed on Sep 1, 2020)

${ }^{x i v}$ A United Nations report warned that gains in gender equality are vulnerable to being reversed by the epidemic. .See this UN report:

https://www.un.org/sexualviolenceinconflict/wp-content/uploads/2020/06/report/policy-briefthe-impact-of-covid-19-on-women/policy-brief-the-impact-of-covid-19-on-women-en-1.pdf (accessed on Aug. 21, 2020)

${ }^{x \mid}$ For the sake of comparison, in the United States the virus has had "a greater impact on African-American, Latinx, and Indigenous communities." Finchelstein and Stanley (2020).

xlviSee his speech in this link : https://www.un.org/africarenewal/web-

features $/ \%$ E2\%80\%9Ctackling-inequality-pandemic-new-social-contract-new-

era\%E2\%80\%9D (accessed on July 29, 2020)

\section{Sample of Questions Asked to Interviewees}

\section{A. Demographic and socio-economic profile}

1. Gender :

2. Place of birth : city?

3. Age :

4. Marital status :

5. Kids : 


\section{Your current place of residence?}

\section{B. Education, skills, and livelihood}

11. What is your highest level of education?

12. Where did you go to school/university?

13. What's your job? Before the pandemic? And now?

14. How do you support your family? Is your husband also helping you?

15. Do you leave family members behind? If yes, what is your relationship to them?

16. Who is taking care of them and of your children in your absence?

17. Where do children work in their homes? Do they have a room of their own?

\section{Family}

14. Talk to me about your family's situation during the pandemic.

15. Have you kept or lost your job during the pandemic?

16. Has your spouse kept or lost his / her job? If not, how do you cope?

17. Do you work from home? How? Do you have a private space for teleworking?

18. How much time do you spend on teleworking per day? And how much time do you devote to your children, cooking and other housework?

19. What words would do you use to describe the current situation? How would you describe your own situation?

20. Does your husband help with the housework? How?

21. Does he help with children's homework and schooling? How?

22. How has your family been impacted by the pandemic?

23. How are you dividing your time between raising your children, telework, and housework?

24. How is your degree, level of education and type of job affecting your employment and your sense of job security? Have you or a member of your family experienced discrimination or violence during the pandemic? At home? Or in the public space?

25. What is the impact of the pandemic on women and girls?

26. What is its impact on gender relations?

27. What are the obstacles that you have encountered during this period?

28. How do you manage for survival?

\section{City or village context and social services during the crisis}

29. Apart from friends and family, in case of need, do you have contacts with other people around you (social workers, public officers, trade unions, volunteers, social cooperatives, institutional representatives, etc.)?

30. Are you a member of a formal or informal group, such as an NGO, volunteering, selforganized rights claiming groups, etc. If yes, what do you to help others?

31. In the neighborhood where you live, do you feel alone? have you established relationships? If yes, with whom?

32. Are you in some way involved in micro-entrepreneurial initiatives (as entrepreneur, supplier, helper, delivering or other forms). If yes, from when?

33. Have you joined any social network, civil society or religious group for help? If yes, has it helped you and your family during the crisis? If so, how has it helped you and your family?

34. What are the main services you use in the city during the pandemic (food stores, utilities, social services, health services, etc.)?

35. How do you get information about such facilities: from friends, social media, television, newspapers, from smartphones, from informal sources, from social workers? Other sources?

36. What do you want the State to provide? 


\section{References}

Abouzzouhour, Y. (2020). "COVID in the Maghreb: Responses and Impacts." Project for Middle East Political Science. Retrieved from: https://pomeps.org/covid-in-the-maghreb-responses-and-impacts (accessed on Dec. 12, 2020)

Abu-Habib, L. (2020). Unequal Gender Relations and the Subordination of Women in the MENA Region: What the Covid-19 Pandemic Has Taught Us. IEMed. Mediterranean Yearbook, 2020; pp.160-164.

Allouche, E, J. (2020). HCP: COVID-19 Crisis Exacerbates Gender Inequality in Morocco. Morocco World News, Aug. 19, 2020. Retrieved from: https://www.moroccoworldnews.com/2020/08/315930/hcp-covid-19crisis-exacerbates-gender-inequality-in-morocco/ (accessed on Sep. 2, 2020)

Alon, T., Doepke, M., Olmstead,-Rumsey, J., \& Tertilt M. (2020). “The Impact of COVID-19 on Gender Equality." Article published on Northwestern University Website in March 2020. Retrieved from: https://faculty.wcas.northwestern.edu/ mdo738/research/COVID19_Gender_March_2020.pdf(accessed on Dec. 17, 2020)

Altonji, J, G., Kahn, L., \& Speer, J, D. (2016). "Cashier or Consultant? Entry Labor Market Conditions, Field of Study, and Career Success." Journal of Labor Economics, 34(S1); pp. 361-401.

Bowleg, L. (2020). We're Not All in This Together: On COVID-19, Intersectionality, and Structural Inequality. American Journal of Public Health. 110(7) pp. 917. Retrieved from:

https://www.ncbi.nlm.nih.gov/pmc/articles/PMC7287552/ (accessed on Jan. 18, 2021)

Brechenmacher, S., \& Hubbard, C. (2020). "How the Coronavirus Risks Exacerbating Women's Political Exclusion." Carnegie Endowment for International Peace. Retrieved from:

https://carnegieendowment.org/2020/11/17/how-coronavirus-risks-exacerbating-women-s-political-exclusionpub-83213 (accessed on Dec. 17, 2020)

Chang, W. (2020). "Understanding the COVID-19 Pandemic from a Gender Perspective." Taiwanese Journal of Obstetrics and Gynecology. 59(6); pp. 801-807. Retrieved from:

https://www.sciencedirect.com/science/article/pii/S1028455920302151 (accessed on Dec. 20, 2020)

Collins, P. H. (2008). Black Feminist Thought: Knowledge, Consciousness, and the Politics of Empowerment. New York: Routledge.

Crenshaw, K., N G., Gary, P., \& Kendall, T. (1996). Critical Race Theory: The Key Writings That Formed the Movement. New York: The New Press.

Darhour, H., \& Dahlerup, D. (2013). "Sustainable Representation of Women Through Gender Quotas: A decade's Experience in Morocco." Women Studies International Forum, 43(2); pp.132-142.

Davis, S., J von Wachter, T., Robert, H., \& Richard, R. (2011). "Recessions and the Costs of Job Loss." Brookings Papers on Economic Activity, pp. 1-72.

Ekberg, J., Richard, E., \& Guido, F. (2013). "Parental Leave - A Policy Evaluation of the Swedish "DaddyMonth" Reform." Journal of Public Economics, 97; pp. 131-143.

Ennaji, M. (2020)."The Challenges of Post-COVID-19 Recovery in Morocco." Morocco World News of July 7 , 2020. Reteieved from: https://www.moroccoworldnews.com/2020/07/307656/the-challenges-of-post-covid-19recovery-in-morocco/

Ennaji M. (2019). Ed. Le mariage des filles mineures au Maghreb. Fès: Centre Sud Nord.

Ennaji, M. (2018). "Morocco's Experience in Gender Gap Reduction in Education." Journal of Gender and Women's Studies, 2(1).

Ennaji, M. (2015). "Women and Political Participation in Morocco and North African States." In Mino Vianello and Mary Hawkesworth (eds.), Gender and Power: Towards Equality and Democratic Governance (pp. 3552). London: Routledge.

Ennaji, M. (2011)."Violence against Underage Housemaids in Morocco."In Salhi, Zahia (ed.). Gender and Violence in Muslim Societies. London: I.B. Tauris, pp. 131-157.

Ennaji, M. (2008). "Steps to the Integration of Moroccan Women in Development." The British Journal of Middle Eastern Studies ,35(33); pp. 339-348.

Ennaji, M. (2006). "Social policy in Morocco," in M. Karshenas and V. Moghadem (eds.), Social Policy in the Middle East. New York: Palgrave Macmillan and UNRISD, pp. 116-127.

Ennaji, M., \& Sadiqi, F. (2012). "Women's Activism and the New Family Code Reforms." The IUP Journal of History and Culture, 6(1); pp. 1-19.

Farré, L. \& González, L. (2019). “Does Paternity Leave Reduce Fertility?” Journal of Public Economics, 172(issue C); pp. 52-66.

Finchelstein, F., \& Stanley, J. (2020). A COVID Genocide in the Americas? The Project Syndicate. Retrieved from: https://www.project-syndicate.org/commentary/trump-bolsonaro-covid-genocide-politically-motivatedneglect-by-federico-finchelstein-and-jason-stanley-2021-01 (accessed on Jan. 19, 2020) 
Friedman, S. J. (2010). “A Tale of Two Economic Developments: Tunisia and Morocco " Retrieved from: https://repository.upenn.edu/cgi/viewcontent.cgi?article=1141\&context=curej (accessed on Dec. 21, 2020)

Grami, A. (2020). Violence against Women during the Corona Pandemic (in Arabic). Al-hewar Al-mutamadden of April 16, 2020. Retrieved from: https://www.ahewar.org/debat/show.art.asp?aid=673471 (accessed on Dec. 29, 2020).

Kasraoui, S. (2020. "HCP: 45\% of Moroccan Men Help With Housework." Morocco World News. Retrieved from: https://www.moroccoworldnews.com/2020/07/312235/hcp-45-of-moroccan-men-help-with-housework/ (accessed on Sep. 2, 2020)

Kleven, H., Camille, L., \& Søgaard, J. E. (2019). "Children and Gender Inequality: Evidence from Denmark.” American Economic Journal: Applied Economics, 11(4); 181-209.

Lambert, A., Cayouette-Remblière, J., Guéraut, E., Le Roux, G., Bonvalet, C., et al. (2020). "Le travail et ses aménagements : ce que la pandémie de covid-19 a changé pour les Français." Population \& Sociétés n 579 , juillet 2020 .

Moghadam, V. (2012). "Democracy and Women's Rights: Reflections on the Middle East and North Africa." In Di Marco, Graciela \&Tabbush, Constaza (Eds.), pp.33-50.

Muller, J. E., \& Nathan, D. G. (2020). "Gendered Effects of School Closures During the COVID-19 Pandemic". The Lancet.com, 395. Retrieved from:

https://www.thelancet.com/pdfs/journals/lancet/PIIS0140-6736(20)31412-4.pdf (accessed on Dec. 19, 2020)

Oreopoulos, P., von Wachter, T., \& Heisz, A. (2012). "The Short- and Long-Term Career Effects of Graduating in a Recession." American Economic Journal: Applied Economics, 4(1); pp. 1-29.

Othmane, B., \& Mama, H. (2016)."An Estimation of the Informal Economy in Morocco." International Journal of Economics and Finance, 8, No. 9;201.

Parker, A., Gillian., M., Graeme, G., \& Samkelisiwe, K. (2020. "How COVID-19 Puts Women at More Risk than Men in Gauteng, South Africa." The Conversation. Retrieved from: https://theconversation.com/howcovid-19-puts-women-at-more-risk-than-men-in-gauteng-south-africa-150570 (accessed on Dec. 21, 2020)

Puri, L. (2020). "Covid-19: An Opportunity to Create a More Equal World." Retrieved from: https://www.hindustantimes.com/analysis/covid-19-an-opportunity-to-create-a-more-equal-world/storykEEZeFa16MQgtAlxTZgE6L.html (accessed on Sep. 4, 2020)

Rivera, C., Yu-Chie h H., Esbry, F., P., \& Dugarova, E. (2020). "Gender Inequality and the COVID-19 Crisis: A Human Development perspective. UNDP Report”: Retrieved from: http://hdr.undp.org/sites/default/files/covid19_and_human_development_-_gender_dashboards_final.pdf (accessed on Dec. 19, 2020)

Sadiqi, F. (2016). Ed. Women's Movements in Post-"Arab Spring" North Africa (Comparative Feminist Studies). New York: Palgrave.

Sadiqi, F. \& Ennaji, M. (2006). "The Feminization of Public Space: Women's Activism, the Family Law, and Social Change in Morocco." Journal of Middle East Women's Studies, 2(2); pp. 86-114.

Sharafeldine, M. (2020). "COVID-19 and the Necessity of Muslim Family Law Reform in the Arab World." Jadaliya. Retrieved from:

https://www.jadaliyya.com/Details/41211/COVID-19-and-the-Necessity-of-Muslim-Family-Law-Reform-in-theArab-World (accessed on Dec; 21, 2020)

Schwandt, H., \& von Wachter, T. (2019). "Unlucky Cohorts: Estimating the Long-Term Effects of Entering the Labor Market in a Recession in Large Cross-Sectional Data Sets." Journal of Labor Economics, 37(S1); pp. $161-198$.

Zaghloul, Y. (2020). "Framing Nationalism in times of a pandemic: The Case of Morocco." Project for Middle East Political Science. Reterived from:

https://pomeps.org/framing-nationalism-in-times-of-a-pandemic-the-case-of-morocco (accessed on Sep. 10, 2020)

Zoglin, K. (2009). “Morocco's Family Code: Improving Equality for Women.” Human Rights Quarterly, 31; pp. 964-984. 